\title{
Paradiplomation of The Island Cluster as an Effort to Increase Exports of Maluku Nutmeg
}

\author{
Dyah Ridhul Airin Daties ${ }^{1 *}$, Efie Baadilla ${ }^{2}$ \\ 1, 2, Faculty of Law Pattimura University, Ambon, Indonesia \\ *E-mail: dyahdatiesant232511@gmail.com
}

\begin{tabular}{l}
\hline Article Info \\
\hline Keywords: \\
Nutmeg; \\
Paradiplomacy; \\
Islands. \\
\\
\\
DOI: \\
10.47268/sasi.v27i4.684 \\
\hline
\end{tabular}

Abstract
Nutmeg is a spice plant native of the Maluku islands that have been traded
and cultivated for generations in the form of smallholder plantations in
most of the Maluku islands. However, currently, Maluku's nutmeg exports
have decreased. Therefore, the Maluku government must be
perspicaciously smart to read every opportunity so that the potential of
natural resources can be utilized optimally for the welfare of the region.
This research is normative juridical research, with the type of library
research. Maluku Province is a province characterized by islands. This
phenomenon is the background for the birth of the concept of island cluster
development. Through the concept of island cluster development, the
Maluku provincial government hopes that each island group realizes the
potential of their respective regions and strives to develop this potential for
the independence of each island group, especially in increasing Maluku
nutmeg exports.

\section{A. INTRODUCTION}

Nutmeg from Maluku or known as Pala Banda (Myristica fragrans Houtt) is one of the mainstay potential export commodities of the Maluku regional government, as a source of economic growth and regional income. Nutmeg is a spice plant native to the Maluku islands that have been traded and cultivated for generations in the form of smallholder plantations in most of the Maluku islands. Maluku nutmeg products are superior in the world market because they have a distinctive aroma and high oil yield. ${ }^{1}$ In Indonesia, there are several types of nutmeg cultivated by farmers, including Myristica Fragrans Houtt (Banda nutmeg), Myristica Succedanea (Ternate nutmeg), and Myristica Argentea (Papua nutmeg). The quality of Maluku nutmeg is superior to other types, especially from the content of myristicin volatile components.

The triumph of Banda nutmeg, the historical spice which became the reason for the Breda agreement in 1667 between the Dutch and the British who agreed to exchange the island of Run in the Banda Islands with the island of Manhattan in New York, United States, deserves serious attention from the local government of the Maluku province as the main source of Regional Original Income (PAD). The fate experienced by PT. Ollop is one example of the case of the Maluku local government's lack of seriousness in protecting the typical spice commodity

1 Bustaman, S. (2007). Prospek dan Strategi Pengembangan Pala Di Maluku. Perspektif, 6(2), 68-74. 
of the Maluku islands. PT. Ollop was founded in the Hila village, Central Maluku district in 2006 by a family from the Hila village who had long lived in the Netherlands. PT. Ollop is an exporter of nutmeg and clove spices, as well as an initiator of organic cultivation in the province of Maluku, and has received an organic certificate from the Rainforest Alliance assessment agency. Especially for nutmeg, every year this company exports 160 tons of nutmeg seeds to the Netherlands with a turnover of 15 billion rupiahs. PT. Ollop in the Netherlands is Verstegen Spices and Sauces BV, a company engaged in the spice trade in the city of Rotterdam, Netherlands. The company has been renowned as a major supplier of quality spices and natural ingredients in Europe since the 20th century. PT. Ollop succeeded in meeting the demand for quality nutmeg from Verstegen, namely export nutmeg with whole seeds, not broken, without holes from insect hoists, maximum moisture content of $11 \%$, and shiny seed coats.

However, in 2016, the export of nutmeg PT. Ollop was rejected by its partner, Verstegen Spices and Sauces BV. It is suspected that the nutmeg was deliberately damaged by the nutmeg trading mafia, while at the port of Surabaya for the aflatoxin test process at the Surabaya city laboratory, East Java. Nutmeg aflatoxin test cannot be carried out in Maluku province, because the laboratory owned by the Maluku provincial government does not meet European Union standards. As a result, companies that have succeeded in building mutually beneficial partnerships and entrepreneurship in the management of regional superior products based on organic and sustainable products that are highly competitive, and have succeeded in improving the welfare of the people of the countries in the Leihitu peninsula, Central Maluku district, have finally gone out of business.

Local governments throughout Indonesia must be smart to read every opportunity so that the potential of natural resources (SDA) can be utilized optimally for the welfare of the region. No matter how large the amount of rupiah disbursed by the central government through the DAU and DAK to local governments, it will be in vain if it is not used effectively, creatively, and innovatively. Especially in this era of the industrial revolution 4.0, we have felt the impact on various aspects of life, the penetration of disruptive technology makes changes happen faster. Local governments are required to continue to develop innovation, management, and risk management. All of this, of course, cannot be carried out by the local government alone, especially by only expecting an absolute contribution from the central government. The expansion of the role of regional governments in the field of foreign cooperation requires regions to carry out diplomacy that can make a real contribution to the welfare of their regions.

\section{B. RESEARCH METHODS}

This research is normative juridical research, with the type of library research. In order to support this research process, the approach used is the statute approach and the conceptual approach to analyze the juridical aspects of the paradiplomacy of island groups in an effort to increase Maluku nutmeg exports.

\section{RESULTS AND DISCUSSION}

Nutmeg plants have a historical value attached to the people of Maluku. Rumphius in 1743 stated that: "God who is wise in giving wealth has allocated nutmeg and clove plants for the Moluccas." ${ }^{2}$ Unfortunately, currently, several problems make it difficult for Maluku nutmeg exports to meet the demands of the export market, especially in Europe, including:

1) Low knowledge of Maluku nutmeg farmers regarding environmentally friendly and sustainable nutmeg plantation procedures;

2) The marketing of people's nutmeg in Maluku has not been organized into a single marketing system because no institution specifically handles the marketing of 
nutmeg. Farmers are still free to sell nutmeg products to collectors in the village or sub-district towns and sub-district collectors sell their products in the district or in the provincial city. This marketing system causes the price of nutmeg at the farm level to be low.

3) Transportation is still the main obstacle in marketing nutmeg products. In general, roads and bridges connecting nutmeg production centers have not yet been built, so farming costs are high, and selling prices are less competitive. This condition causes marketing to tend to be a monopoly and purchasing is dominated by the bondage system which is detrimental to farmers.

4) Another obstacle to the development of nutmeg agribusiness in Maluku is the absence of a shipping port at the production center point.

The geographical condition of the Maluku region, which is characterized by islands, cannot be denied giving rise to empirical phenomena that can be seen concretely related to the characteristics of areas that are in direct contact with the ocean or areas characterized by islands, namely: ${ }^{3}$

(a) limited facilities and infrastructure for basic services;

(b) limited local financial capacity;

(c) very minimal sea and air transportation facilities and infrastructure;

(d) transportation costs for government services are very expensive;

(e) limited public accessibility in general;

(f) the existence of physical and social isolation;

(g) there is a very high fiscal dependence on the government;

(h) the quality of various government services, both public and civil services;

(i) there are still economic disparities between regions; as well as

(j) the low quality of human resources.

This phenomenon is the background for the birth of the concept of island cluster development. Through the concept of island cluster development, the Maluku provincial government hopes that each island group realizes the potential of their respective regions and strives to develop this potential for the independence of each island group. The definition of island clusters in the Maluku Province Regional Regulation (PERDA) No. 2 of 2010 concerning the Maluku Regional Development Planning Deliberation (Musyawarah Perencanaan Pembangunan Daerah Maluku) is a collection of islands that are geographically close to each other, where there are close links and dependencies/interactions between ecosystems, economic, social and cultural conditions, both individually and in groups". Based on this definition, a group of islands in Maluku was formed, taking into account the characteristics of each island first. Finally, based on the Maluku Province Regional Spatial Plan for 2007 - 2027, 12 island clusters have been determined as follows:

(1) Island cluster I, including Buru Island, the service center in Namlea city.

(2) Island Cluster II, covering West Seram; service center in the city of Piru / Mainland Honipopu.

(3) Island Cluster III, covering North Seram; service center in the city of O.

(4) Island cluster IV, covering East Seram; service center in the city of Bula.

(5) Island Cluster V, covering South Seram; service center in Masohi city.

(6) Island cluster VI, which includes Banda islands and TNS; service center in Banda Naira city.

(7) Island Cluster VII, which includes Ambon Island and Lease Islands; service center in Ambon city.

(8) Island Cluster VIII, including the Kei Islands; service center in Tual city/

${ }^{3}$ Leatemia, J. (2010). Pengaturan Hukum Terhadap Kewenangan Daerah Di Wilayah Laut, (Disertasi: Universitas Hasanuddin), p. 140.

439 |S A S Volume 27 Issue 4, October - December 2021 
(9) Island Cluster IX, including the Aru Islands; service center in the city of Dobo.

(10) Island Cluster X, including the Tanimbar Islands; service center in the city of Tepa.

(11) Island Cluster XI, including the Babar Islands; service center in the city of Tepa.

(12) Island Cluster XII, covering the Southern and Wetar Islands; service center in Kisar city.

Map 1.

\section{Island Cluster Map}

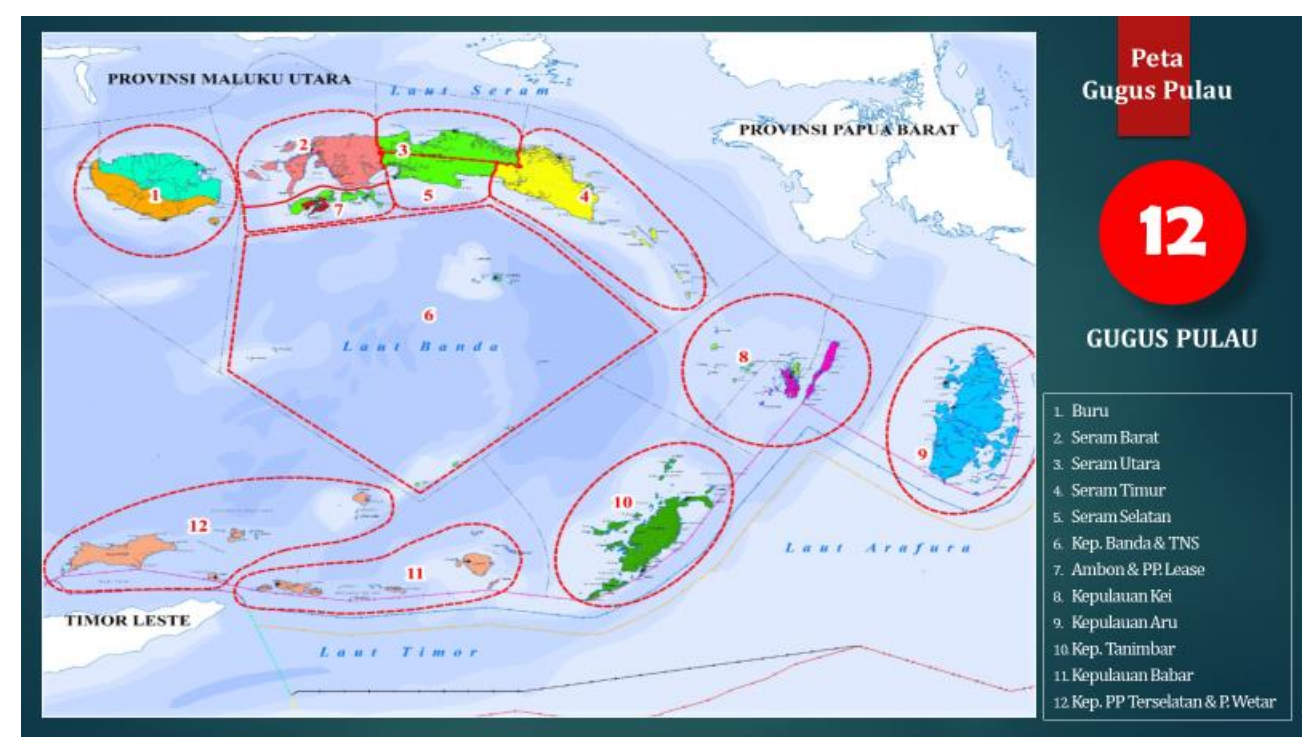

Source : Bappeda Maluku Province, 2018.

The development of island clusters is carried out in several approaches, including:

1) Able to develop their own potential independently.

2) Realizing integration in the use of various resources.

3) Integration between development sectors through the space utilization process, in the context of achieving sustainable development goals.

The development of the 12 island clusters is expected so that each island group becomes an independent region, which is able to meet the needs of its territory and sustainably develop its potential. In each island group, a growth center for an island group has been established, the development of which is expected to be able to encourage the surrounding area or the back area within the island group, so as to ensure accessibility, availability, acceptability, and sustainability of the implementation, governance, implementation of development, and community services.

Based on the concept of island cluster development, three areas for nutmeg development were determined, namely:

1) Development Area I Development area I covers the Regencies of Aru (Wokam Island) and West Southeast Maluku (Damer, Romang, and Babar Islands).

2) Development Area II Development area II covers the regencies of Southeast Maluku, Central Maluku, Buru, West Seram and East Seram.

3) Development Area III Development area III covers Ambon Island which has port and airport facilities but a limited plantation area.

The three nutmeg development areas have identified the opportunities and challenges. Contemporary international cooperative relations give rise to a new entity called a sub-national entity. Included in this sub-national entity are elements of government under the central government of a sovereign state, namely local governments, be it states; province; prefecture; 
city to district. These sub-national entities are referred to as residents of the gray area because unlike other international legal subjects that are independent and have specific issues, subnational entities have a character that is structurally similar to a state, but is not essentially a state.

The increase in regional authority in the domestic and international fields is the result of the increasing flow of information, capital movements, and human immigration which move in a complex manner across cultures, across countries, and across continents, so that regions, both provinces and districts/cities, will not be able to avoid international influence, as well as provide opportunities for regions to take advantage of foreign cooperation for the benefit of regional development. This will naturally expand the role of local government. ${ }^{4}$

Increased government authority in international cooperation as regulated in Law No. RI. 23 of 2014 concerning Regional Government (Pemerintahan Daerah), Article 363 is:

(1) In the context of improving the welfare of the people, regions may enter into a cooperation based on considerations of efficiency and effectiveness of public services and mutual benefit.

(2) The cooperation as referred to in paragraph (1) may be carried out by the Region by:

a) Other regions;

b) Third-party; and/or

c) Institutions or local governments abroad in accordance with the provisions of laws and regulations.

Regional cooperation with institutions and/or regional governments abroad includes: ${ }^{5}$

a) Development of science and technology;

b) Culture Exchange;

c) Improvement of technical capability and government management;

d) Promotion of regional potential; and

e) Other cooperation that does not conflict with the provisions of the legislation.

The authority to establish international interactions is given to provincial and district/city governments in Indonesia as a response to the strong world trend in competing with each other to obtain optimal results. This authority is a door for local governments to build international networks to increase competitiveness and expand regional investment. It is inconceivable that at a time when the world is currently in an era of openness and competition, there are still local governments that have not opened up or have not taken advantage of the opportunities and challenges of international cooperation.

See Article 367 of the Law of the Republic of Indonesia Number 23 of 2014 concerning Regional Government (Pemerintahan Daerah). One of the keys for a region to be able to attract foreign cooperation is to highlight the characteristics/specialties/specialties of the region. Maluku Province, as an archipelagic province, has a great opportunity to improve the welfare of the region through regional foreign cooperation programs that are adapted to the concept of regional development, namely the concept of island cluster development.

Diplomacy carried out by a country today is not enough to rely solely on diplomacy carried out by the central government. The role of local governments is now increasingly important as part of multi-track diplomacy. The current local government must play an active role in seeking opportunities for economic diplomacy, not only for the progress of the region

${ }^{4}$ Damayanti, C. (2012). potensi paradiplomasi dalam mendukung kinerja Diplomasi indonesia menuju komunitas asean. Jurnal Transformasi, 14(22).

5 Article 367 of the Law of the Republic of Indonesia Number 23 of 2014 concerning Regional Government (Pemerintahan Daerah) 
but also for the national interest. Local governments become partners in diplomacy because many international collaborations involve regional interests. ${ }^{6}$

In order to improve the welfare of the people, regions can enter into a cooperation based on considerations of efficiency and effectiveness of public services as well as mutual benefit. Cooperation carried out by regions can be carried out with other regions, with third parties, and with institutions abroad in accordance with statutory regulations. ${ }^{7}$ Regional government cooperation abroad includes: ${ }^{8}$

a) Development of science and technology;

b) Culture Exchange;

c) Improvement of technical capability and government management;

d) Promotion of regional potential; and

e) Other cooperation that does not conflict with the provisions of the legislation.

As an archipelago, $92.4 \%$ sea and $7.6 \%$ land, approximately 1340 small islands, is an opportunity for local governments to pioneer foreign cooperative relations that can help the government overcome the challenges of geographical conditions for archipelagic areas. The concept of island group paradiplomacy actually tries to connect the concept of island cluster development into the Maluku regional government's foreign relations planning strategy, especially in increasing Maluku exports of nutmeg.

\section{CONCLUSION}

Island group paradiplomacy must be implemented comprehensively, cannot be implemented sectorally. The Maluku local government must immediately initiate a foreign cooperation relationship that can help local governments improve the quality of superior nutmeg commodities in the 3 nutmeg development areas. The problem of inter-island connectivity is still a challenge for increasing Maluku nutmeg exports. For this reason, regional diplomacy needs to be directed to find opportunities for international cooperation that can overcome this. Paradiplomacy of island groups should be directed to maximize the potential of natural resources characterized by islands. This of course requires efficient regulatory support; and the ability of human resources who understand diplomacy techniques, relations, and international law well. So far, as acknowledged by the local government of Maluku, there are no human resources who are well versed in issues relevant to regional foreign relations. For example, the lack of human resources who master the field of international treaty law and foreign investment law.

\section{REFERENCES}

\section{Journal}

[1] Bustaman, S. (2007). Prospek dan Strategi Pengembangan Pala Di Maluku. Perspektif, 6(2), 68-74.

[2] Damayanti, C. (2012). potensi paradiplomasi dalam mendukung kinerja Diplomasi indonesia menuju komunitas asean. Jurnal Transformasi, 14(22).

[3] Pujayanti, A. (2018). Peran daerah dalam diplomasi ekonomi. Jurnal Politica Dinamika Masalah Politik Dalam Negeri dan Hubungan Internasional, 7(1).

${ }^{6}$ Pujayanti, A. (2018). Peran daerah dalam diplomasi ekonomi. Jurnal Politica Dinamika Masalah Politik Dalam Negeri dan Hubungan Internasional, 7(1).

7 See Article 367 of the Law of the Republic of Indonesia Number 23 of 2014 concerning Regional Government (Pemerintahan Daerah)

8 See Article 363 of the Law of the Republic of Indonesia Number 23 of 2014 concerning Regional Government (Pemerintahan Daerah)

442|S ASI Volume 27 Issue 4, October - December 2021 
Online/World Wide Web, Thesis etc

[4] Leatemia, J. (2010). Pengaturan Hukum Terhadap Kewenangan Daerah Di Wilayah Laut, (Disertasi: Universitas Hasanuddin). 